\title{
Strategi Modeling the Way untuk Meningkatkan Keterampilan Berbicara dan Hasil Belajar Peserta Didik di SD Negeri 3 Candisari Purwodadi Kabupaten Grobogan
}

\author{
Hermin Dwi Kurniati*, Ervina Eka Subekti, Kuswandari \\ Pendidikan Profesi Guru, Pendidikan Guru Sekolah Dasar, Universitas PGRI Semarang \\ *Corresponding Author. Email: hermindwikurniati94@gmail.com
}

\begin{abstract}
This study aims to apply the Modeling The Way strategy to improve speaking skills and learning outcomes in learning Theme 9 for fifth grade students of SD Negeri 3 Candisari. This research is a classroom action research conducted in three cycles. The subjects of this study were the fifth grade teachers and the fifth grade students, totaling 14 people. Collecting data through interviews, observation, and documentation. As for the validity of the data using source triangulation and techniques triangulation. The results showed an increase in speaking skills, namely: 1) In the first cycle the first meeting reached $35.71 \%, 2$ ) the second meeting increased to $42.85 \%, 3$ ) in the second cycle the first meeting increased to $50 \%, 4$ ) the second meeting increased to $57.14 \%, 5$ ) in the third cycle the first meeting increased to $71.42 \%, 6)$ the second meeting increased to $85.71 \%$. For learning outcomes also increased, namely: 1) In the first cycle the first meeting reached $35.71 \%, 2$ ) the second meeting increased to $42.85 \%, 3$ ) in the second cycle the first meeting increased to $42.85 \%, 4$ ) the second meeting increased to $42.85 \%$ the second meeting increased to $50 \%, 5$ ) in the third cycle the first meeting increased to $78.57 \%, 6)$ the second meeting remained $78.57 \%$. The conclusion of this study is that the Modeling The Way strategy can improve speaking skills and learning outcomes in fifth grade students. SD Negeri 3 Candisari in 2010/2021 academic year.
\end{abstract}

Abstrak: Penelitian ini bertujuan menerapkan strategi Modeling The Way untuk meningkatkan keterampilan berbicara dan hasil belajar dalam pembelajaran Tema 9 pada peserta didik kelas V SD Negeri 3 Candisari. Penelitian ini merupakan penelitian tindakan kelas yang dilaksanakan dalam tiga siklus. Subyek penelitian ini yaitu guru kelas $\mathrm{V}$ dan peserta didik kelas V yang berjumlah 14 orang. Teknik pengumpulan data melalui wawancara, observasi, dan dokumentasi. Adapun untuk validitas data menggunakan triangulasi sumber dan triangulasi teknik. Hasil penelitian menunjukkan adanya peningkatan keterampilan berbicara yaitu: 1) Pada tahap siklus I pertemuan pertama mencapai $35,71 \%, 2$ ) pertemuan kedua meningkat menjadi $42,85 \%, 3$ ) pada siklus II pertemuan pertama meningkat menjadi 50\%, 4) pertemuan kedua meningkat menjadi $57,14 \%, 5)$ pada siklus III pertemuan pertama meningkat menjadi $71,42 \%, 6)$ pertemuan kedua meningkat menjadi $85,71 \%$. Untuk hasil belajar juga mengalami peningkatan yaitu: 1) Pada tahap siklus I pertemuan pertama mencapai $35,71 \%$, 2) pertemuan kedua meningkat menjadi $42,85 \%, 3$ ) pada siklus II pertemuan pertama meningkat menjadi $42,85 \%$, 4) pertemuan kedua meningkat menjadi $50 \%, 5$ ) pada siklus III pertemuan pertama meningkat menjadi $78,57 \%$,6) pertemuan kedua tetap 78,57\%. Kesimpulan penelitian ini yaitu strategi Modeling The Way dapat meningkatkan keterampilan berbicara dan hasil belajar pada peserta didik kelas V SD Negeri 3 Candisari tahun ajaran 2010/2021.

\author{
Article History \\ Received: 23-05-2021 \\ Revised: 08-06-2021 \\ Accepted: 20-06-2021 \\ Published: 07-07-2021
}

\section{Key Words:}

Modeling the Way, Speaking Skills, Learning Outcomes.

\section{Sejarah Artikel}

Diterima: 23-05-2021

Direvisi: 08-06-2021

Disetujui: 20-06-2021

Diterbitkan: 07-07-2021

\section{Kata Kunci: \\ Modeling the Way, Keterampilan Berbicara, Hasil Belajar.}

How to Cite: Kurniati, H., Subekti, E., \& Kuswandari, K. (2021). Strategi Modeling The Way untuk Meningkatkan Keterampilan Berbicara dan Hasil Belajar Peserta Didik di SD Negeri 3 Candisari Purwodadi Kabupaten Grobogan. Jurnal Paedagogy, 8(3), 304-310. doi:https://doi.org/10.33394/jp.v8i3.3890 


\section{Pendahuluan}

Pendidikan mempunyai peran utama dalam kehidupan manusia. Keadaan suatu bangsa sangat dipengaruhi dengan bagaimana kondisi sumber daya manusia yang ada dalam bangsa tersebut. Melalui pendidikan, nilai dalam masyarakat dapat dilestarikan dengan menerapkan nilai yang ada di masyarakat itu sendiri. Komponen dasar sebagai tonggak penyempurnaan program pendidikan di sekolah dasar salah satunya adalah keterampilan berbicara dalam pembelajaran.

Bahasa memiliki fungsi sebagai alat komunikasi manusia. Bahasa sebagai alat komunikasi bertujuan memenuhi sifat manusia sebagai makhluk sosial yang perlu berinteraksi dengan sesama manusia. Secara umum, bahasa memiliki peran penting dalam perkembangan intelektual, sosial, dan emosional siswa. Bahasa juga merupakan penunjang keberhasilan dalam mempelajari semua bidang studi. Pembelajaran bahasa diharapkan dapat membantu peserta didik mengenal dirinya, budayanya dan budaya orang lain, mengemukakan gagasan dan perasaanya, serta berpartisipasi dalam masyarakat yang menggunakan bahasa tersebut. Salah satu aspek berbahasa yang harus dikuasai oleh peserta didik adalah berbicara, sebab keterampilan berbicara menunjang keterampilan lainnya (Tarigan, 2008; Rahim, 2016). Kegiatan berbicara diawali dari suatu pesan yang harus dimiliki pembicara yang akan disampaikan kepada penerima pesan, sehingga penerima pesan dapat menerima atau memahami isi pesan tersebut.

Sukmayati (2014) menyatakan bahwa "Speaking is an interaction between the speaker and listener where the aims are to deliver speakers' information or intention during the conversation". Dari pernyataan diatas, Sukmayati menyatakan bahwa berbicara adalah interaksi antara pembicara dan pendengar dengan tujuan untuk memberikan sebuah informasi. Pembicara berusaha agar pendengar memahami atau menangkap makna apa yang disampaikannya. Selanjutnya, Maya (2017) berbicara itu lebih dari sekadar mengucapkan bunyi-bunyi atau kata-kata saja, berbicara merupakan realisasi pikiran, gagasan, atau perasaan yang disampaikan dalam bentuk ujaran kepada orang lain untuk tujuan tertentu. Keterampilan berbicara merupakan salah satu keterampilan berbahasa yang harus diajarkan dan dikuasai peserta didik karena keterampilan ini secara langsung berkaitan dengan seluruh proses belajar di sekolah. Keterampilan berbicara penting dikuasai peserta didik agar mampu mengembangkan kemampuan berpikir, membaca, menulis, dan menyimak (Muliasih, 2019; Rahmawati, 2018).

Berdasarkan hasil observasi di SD Negeri 3 Candisari Kecamatan Purwodadi Kabupaten Grobogan, sedikit peserta didik yang mempunyai keterampilan berbicara karena peserta didik cenderung diam atau pasif. Hal ini ditambah dengan kelas V pada kurikulum 2013 sudah mulai banyak kegiatan diskusi. Kegiatan diskusi biasanya diakhiri dengan kegiatan mengkomunikasikan hasil diskusinya. Berdasarkan pengamatan di kelas V SD Negeri 3 Candisari peserta didik kelas V berjumlah 14 peserta didik, yang terdiri dari 8 peserta didik laki-laki dan 6 peserta didik perempuan memiliki kelemahan dalam keterampilan berbicara. Peserta didik kelas V SD Negeri 3 Candisari Kecamatan Purwodadi Kabupaten Grobogan, lebih dari 50\% cenderung pasif.

Melihat kondisi di atas, proses pembelajaran di SD Negeri 3 Candisari, keterampilan berbicara yang rendah juga memengaruhi hasil belajar peserta didik yang ikut menurun. Untuk mengatasi masalah tersebut perlu adanya inovasi strategi pembeajaran yang dapat meningkatkan hasil belajar peserta didik. Upaya meningkatkan keterampilan berbicara dan hasil belajar peserta didik di sekolah dasar dapat menggunakan sebuah strategi pembelajaran yang inovatif dan menarik bagi peserta didik agar lebih bersemangat dan termotivasi untuk 
mengikuti proses pembelajaran serta dapat meningkatkan keterampilan berbicara dan hasil belajar peserta didik. Salah satu upaya meningkatkan keterampilan berbicara dan hasil belajar adalah dengan menggunakan strategi pembelajaran Modeling The Way.

Adapun tujuan penelitian ini adalah menerapkan strategi Modeling The Way untuk meningkatkan keterampilan berbicara dan hasil belajar dalam pembelajaran Tema 9 Bendabenda di Sekitar Kita pada peserta didik kelas V SD Negeri 3 Candisari Kecamatan Purwodadi Kabupaten Grobogan.

\section{Metode Penelitian}

Metode penelitian ini menggunakan penelitian tindakan kelas. Menurut Bahri (2012) penelitian tindakan kelas merupakan sebuah kegiatan yang dilaksanakan untuk mengamati kejadian-kejadian dalam kelas untuk memperbaiki praktek dalam pembelajaran agar lebih berkualitas dalam proses sehingga hasil belajar menjadi lebih baik. Penelitian tindakan kelas merupakan proses pengkajian melalui sistem siklus dari berbagai kegiatan pembelajaran (Arikunto, 2010; Suyadi, 2012). Kemmis dan Mc Taggart (dalam Sukardiyanto, 2015) menyatakan langkah-langkah PTK dilaksanakan dengan 4 tahapan yaitu perencanaan (Planning), tindakan (Action), pengamatan (Observation) dan refleksi (Reflection).

Penelitian ini dilaksankan di SD Negeri 3 Candisari pada tahun ajaran 2020/2021. Penelitian dilaksanakan pada semester genap yaitu bulan Maret sampai Juni 2021. Subyek yang melakukan tindakan ini adalah peneliti yang berperan sebagai observer dan guru kelas V. Sedangkan yang menerima tindakan dalam penelitian ini adalah peserta didik kelas V SD Negeri 3 Candisari yang berjumlah 14 peserta didik yang terdiri dari 8 peserta didik laki-laki dan 6 peserta didik perempuan. Data yang dikumpulkan dalam penelitian ini adalah hasil pengamatan tentang keterampilan berbicara terhadap siswa kelas V SDN 3 Candisari dalam proses pembelajaran Bahasa Indonesia melalui strategi Modeling The Way dengan media gambar. Data yang dikumpulkan atau dikaji dalam penelitian ini adalah diperoleh dari data kualitatif. Jenis data yang digunakan berupa tindakan pembelajaran dan perilaku siswa sesuai masalah yang diteliti. Sumber data yang dikumpulkan dalam penelitian ini meliputi: Narasumber, yaitu guru kelas dan siswa kelas V, tempat berlangsungnya proses pembelajaran yaitu di SDN 3 Candisari, dokumen yaitu berupa presensi siswa, daftar nilai dan dokumen lainnya yang dapat dijadikan sumber data yang valid dalam penelitian.

Teknik pengumpulan data adalah suatu cara yang dipakai peneliti untuk memperoleh data yang akan diteliti. Kualitas data penelitian ditentukan oleh kualitas alat pengambilan data atau alat yang diukur. Agar memperoleh data yang sesuai dengan tujuan yang telah ditentukan sebelumnya, maka perlu menggunakan teknik pengumpulan data melalui wawancara, observasi, dokumentasi, dan catatan lapangan. Ismawati (2010) mengatakan bahwa "wawancara, interview, kuesioner lisan adalah sebuah dialog yang dilakukan oleh pewawancara untuk memperoleh informasi dari terwawancara". Indikator keterampilan berbicara dapat diukur melalui saat proses pembelajaran dengan target akhir $75 \%$, indikator keterampilan berbicara meliputi: aspek intonasi, pelafalan, jeda dan kelancaran. Adapun validitas data penelitian menggunakan triangulasi sumber dan teknik.

\section{Hasil Penelitian dan Pembahasan}

Penelitian tindakan kelas yang dilaksanakan pada peserta didik kelas V SD Negeri 3 Candisari terdiri dari 3 siklus. Setiap siklus dilaksanakan 2 pertemuan yang terdiri dari empat tahapan, yaitu : (1) perencanaan tindakan, (2) pelaksanaan tindakan, (3) hasil pengamatan, (4) 
refleksi. Deskripsi tentang hasil penelitian dari siklus I sampai dengan siklus III dapat dijelaskan sebagai berikut:

Sebelum melaksanakan siklus I, peneliti melakukan observasi awal untuk mengetahui kondisi yang ada sekolah tersebut. Berdasarkan hasil observasi peneliti memperoleh data bahwa keterampilan berbicara dan hasil belajar peserta didik kelas V dari 14 peserta didik hanya 2 peserta didik yang mencapai nilai KKM. Hal ini terjadi karena guru menggunakan strategi dan media yang kurang menarik sehingga pembelajaran terlihat monoton. Peserta didik kurang memusatkan perhatian pada saat pembelajaran dan tidak mendengarkan saat guru menerangkan materi yang diajarkan. Hal ini menunjukan bahwa saat peserta didik diminta guru mengutarakan pendapatnya mengenai materi atau pada saat guru memberikan pertanyaan lisan banyak peserta didik yang tidak mau menjawab pertanyaan yang diberikan. Kemudian peneliti merencanakan dan menetapkan untuk menggunakan strategi dan media pembelajaran baru yaitu pembelajaran dengan menggunakan strategi Modeling The Way.

Setelah strategi dan media digunakan pada siklus I, keterampilan berbicara dan hasil belajar peserta didik mengalami peningkatan walaupun belum sesuai target. Peserta didik mencapai indikator berbicara dengan nilai yang baik hanya berjumlah 5 peserta didik atau sekitar $35,71 \%$ pada siklus I pertemuan pertama. Sedangkan peserta didik yang mendapat nilai kurang dari batas minimal adalah 9 peserta didik atau sekitar 64,29\%. Pada siklus I pertemuan kedua peserta didik mencapai indikator berbicara dengan baik berjumlah 6 peserta didik atau sekitar $42,85 \%$ dan peserta didik yang mendapat nilai kurang dari batas minimal adalah 8 peserta didik atau sekitar 57,15\%. Pada hasil belajar peserta didik, untuk siklus I pertemuan pertama, peserta didik yang mencapai indikator keberhasilan adalah 5 peserta didik atau sekitar 35,71\%, sedangkan peserta didik yang belum mencapai indikator keberhasilan adalah 9 peserta didik atau sekitar 64,29\%. Pada siklus I pertemuan kedua peserta didik yang mencapai indikator keberhasilan ada 6 peserta didik atau sekitar $42,85 \%$ dan peserta didik yang belum mencapai indikatr keberhasilan ada 8 peserta didik atau sekitar $57,15 \%$.

Ketika dilanjutkan pada tahap siklus II pertemuan pertama, jelas terlihat bahwa keterampilan berbicara peserta didik kelas V SD Negeri 3 Candisari mengalami peningkatan. Terbukti peserta didik yang mendapatkan nilai baik pada tahap siklus I hanya 6 peserta didik atau sekitar 42,85\%, pada siklus II pertemuan pertama kali ini meningkat menjadi 7 peserta didik atau sekitar 50\%. Pada penilaian hasil belajar, peserta didik yang mencapai indikator keberhasilan masih sama dengan siklus I pertemuan kedua yaitu 6 peserta didik atau sekitar $42,85 \%$.

Setelah itu dilanjutkan pengamatan dan penilaian pada tahap siklus II pertemuan kedua, hasil yang diperoleh menunjukan bahwa keterampilan berbicara peserta didik kelas $\mathrm{V}$ SD Negeri 3 Candisari mengalami peningkatan. Terbukti peserta didik yang mendapatkan nilai baik pada tahap siklus II pertemuan pertama hanya berjumlah 7 peserta didik atau sekitar 50\%, pada tahap siklus II pertemuan kedua kali ini meningkat menjadi 8 peserta didik sekitar 57,14\%. Untuk hasil belajar juga mengalami peningkatan. Peserta didik yang mencapai indikator keberhasilan pada siklus II pertemuan kedua ini adalah 7 peserta didik atau sekitar $50 \%$.

Kemudian dilanjutkan pada tahap siklus III pertemuan pertama, jelas terlihat bahwa keterampilan berbicara peserta didik kelas V SD Negeri 3 Candisari mengalami peningkatan. Terbukti peserta didik yang mendapatkan nilai baik pada tahap siklus II hanya 8 peserta didik atau sekitar 57,14\%, pada siklus III pertemuan pertama kali ini meningkat menjadi 10 peserta didik atau sekitar 71,42\%. Pada penilaian hasil belajar, peserta didik yang mencapai indikator 
keberhasilan mengalami peningkatan yang cukup signifikan yaitu 11 peserta didik atau sekitar 78,57\%.

Pada siklus III pertemuan kedua, keterampilan berbicara peserta didik meningkat menjadi 12 anak atau sekitar 85,71\%, sedangkan pada hasil belajar masih sama dengan siklus III pertemuan pertama yaitu 11 anak atau sekitar 78,57\%. Karena peningkatan keterampilan berbicara dan hasil belajar sudah mencapai indikator keberhasilan, maka penelitian dianggap sudah selesai. Berikut ini merupakan tabel perbandingan prosentase peningkatan keterampilan berbicara peserta didik kelas V pada pembelajaran tema 9 :

Tabel 1. Perbandingan Prosentase Peningkatan Keterampilan Berbicara Peserta

Didik Kelas V SD Negeri 3 Candisari

\begin{tabular}{|c|c|c|c|}
\hline No & Siklus & Pertemuan & Prosentase \\
\hline \multirow{2}{*}{1} & \multirow{2}{*}{ I } & Pertama & $35,71 \%$ \\
\cline { 3 - 4 } & \multirow{2}{*}{2} & Kedua & $42,85 \%$ \\
\hline \multirow{2}{*}{3} & II & Pertama & $50 \%$ \\
\cline { 3 - 4 } & \multirow{2}{*}{ III } & Kedua & $57,14 \%$ \\
\cline { 3 - 4 } & & Pertama & $71,42 \%$ \\
\hline
\end{tabular}

Adapun grafik perbandingan prosentase peningkatan keterampilan berbicara kelas V SD Negeri 3 Candisari dalam pembelajaran Tema 9 pada tabel di atas dapat digambarkan sebagai berikut:

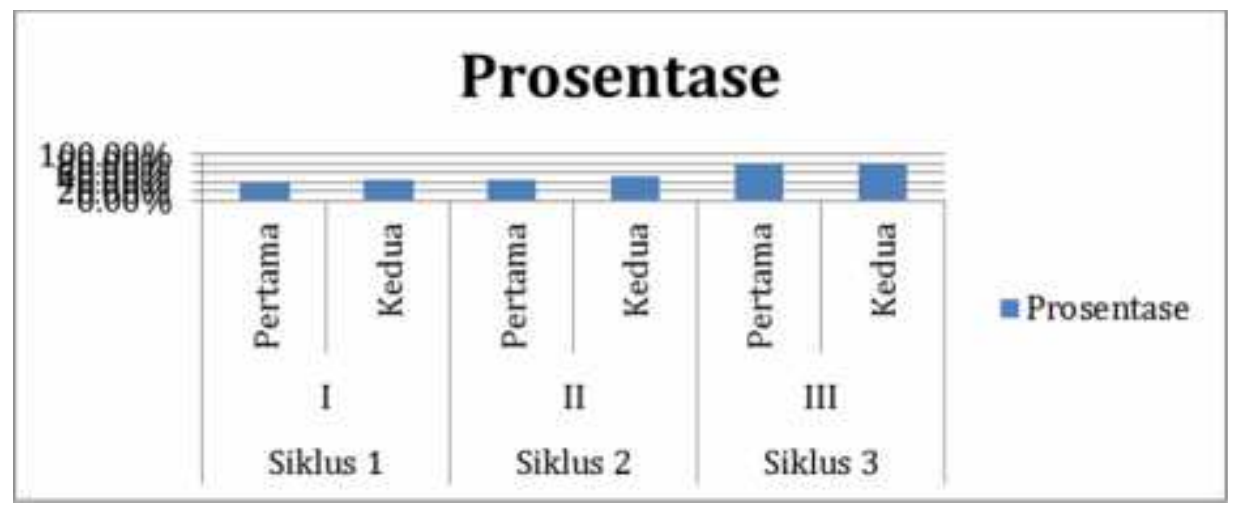

Gambar 1. Perbandingan Prosentase Peningkatan Keterampilan Berbicara Peserta Didik Kelas V SD Negeri 3 Candisari

Berikut ini merupakan tabel perbandingan prosentase peningkatan hasil belajar peserta didik kelas $\mathrm{V}$ pada pembelajaran tema 9 :

Tabel 2. Perbandingan Prosentase Peningkatan Hasil Belajar Peserta Didik Kelas V SD Negeri 3 Candisari

\begin{tabular}{|c|c|c|c|}
\hline No & Siklus & Pertemuan & Prosentase \\
\hline \multirow{2}{*}{1} & \multirow{2}{*}{ I } & Pertama & $35,71 \%$ \\
\cline { 3 - 4 } & \multirow{2}{*}{2} & Kedua & $42,85 \%$ \\
\hline \multirow{2}{*}{3} & \multirow{2}{*}{ II } & Pertama & $42,85 \%$ \\
\cline { 3 - 4 } & \multirow{2}{*}{ III } & Kedua & $50 \%$ \\
\cline { 3 - 4 } & & Pertama & $78,57 \%$ \\
\hline
\end{tabular}

Adapun grafik perbandingan prosentase peningkatan hasil belajar kelas V SD Negeri 3 Candisari dalam pembelajaran Tema 9 pada tabel di atas dapat digambarkan sebagai berikut: 


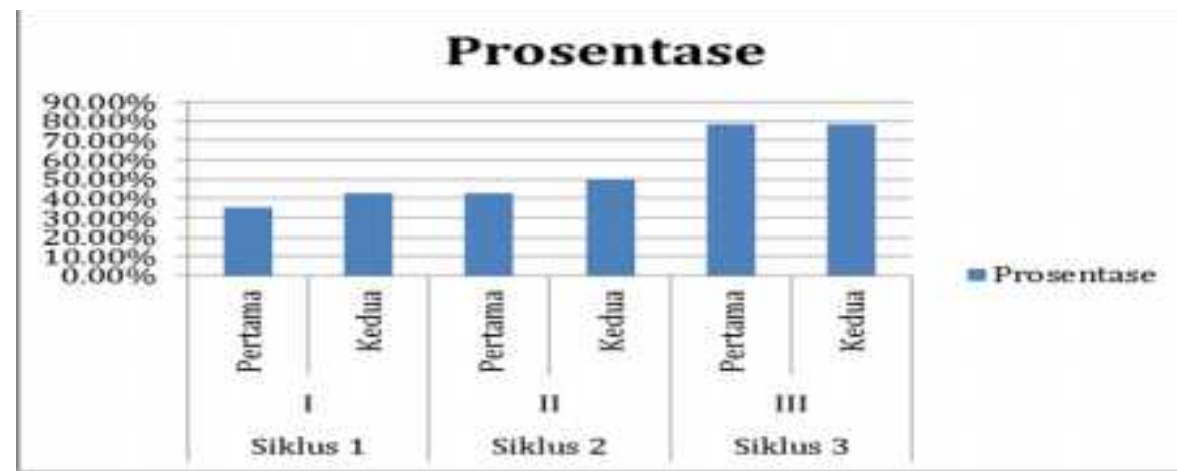

\section{Gambar 2. Perbandingan Prosentase Peningkatan Hasil Belajar Kelas V SD Negeri 3 Candisari dalam pembelajaran Tema 9}

Berdarkan hasil penelitian maka dapat disimpulkan bahwa hipotesis tindakan yaitu strategi Modeling The Way dapat meningkatkan keterampilan berbicara dan hasil belajar pada peserta didik kelas V SD Negeri 3 Candisari tahun 2020/2021 dapat diterima kebenarannya.

\section{Kesimpulan}

Hasil penelitian tindakan yang dilakukan pada peserta didik kelas V SD Negeri 3 Candisari dapat disimpulkan bahwa pembelajaran melalui strategi Modeling The Way dapat meningkatkan keterampilan berbicara dan hasil belajar peserta didik pada Pembelajaran tema 9 tahun ajaran 2020/2021. Keefektifan ini terbukti pada tahap siklus I pertemuan pertama, peserta didik yang memiliki keterampilan berbicara yang baik hanya sekitar 5 peserta didik dari 14 peserta didik yang ada atau sebesar 35,71\%. Sedangkan pada tahap siklus terakhir meningkat menjadi $85,71 \%$. Untuk hasil belajar, pada siklus I pertemuan pertama, peserta didik yang mendapat nilai mencapai batas maksimum adalah 5 peserta didik dari 14 peserta didik yang ada atau sebesar $35,71 \%$. Sedangkan pada siklus terakhir meningkat menjadi 78,57\%. Berdasarkan hasil penelitian tersebut maka dapat disimpulkan bahwa hipotesis tindakan yaitu strategi Modeling The Way dapat meningkatkan keterampilan berbicara dan hasil belajar pada peserta didik kelas V SD Negeri 3 Candisari tahun 2020/2021 dapat diterima kebenarannya.

\section{Saran}

Adapun saran yang disampaikan berdasarkan hasil penelitian ini yakni seorang guru hendaknya menggunakan strategi dan media yang dapat meningkatkan keterampilan berbicara dan hasil belajar peserta didik diantaranya melalui strategi modeling the way. Guru hendaknya memberikan kesempatan merata kepada peserta didik untuk berbicara dan sering memberikan pertanyaan untuk melatih peserta didik berbicara serta memberikan perhatian khusus kepada peserta didik yang masih kurang terampil berbicara dan pasif saat pembelajaran. Selain itu, untuk penelitian selanjutnya diharapkan menggunakan strategi dan media pembelajaran yang lain sebagai alternatif untuk meningkatkan keterampilan berbicara dan hasil belajar peserta didik.

\section{Daftar Pustaka}

Arikunto, S. (2010). Prosedur Penelitian Suatu Pendekatan Praktik. Jakarta: Rineka Cipta Bahri, Aliem. (2012). "Penelitian Tindakan Kelas". Makassar : Universitas Muhammadiyah Makassar. 
Ismawati, Esti. (2010). Metode Penelitian Pendidikan Bahasa \& Sastra. Klaten: Yuma Pustaka

Muliasih, A. (2019). Upaya Meningkatkan Keterampilan Berbicara dengan Menerapkan Metode Sosiodrama (Role Playing) di Kelas V SDN 2 Barejulat. Jurnal Paedagogy, 6(2), 66-73. doi:https://doi.org/10.33394/jp.v6i2.2535

Nupus, Maya Hayatun dan Desak Putu Parmiti. (2017). "Peningkatan Keterampilan Berbicara Melalui Penerapan Metode Show and Tell Siswa SD Negeri 3 Banjar Jawa". Jurnal Ilmiah Sekolah Dasar, 1 (4) 297.

Rahim, A. (2016). Improving Speaking Skill of Eight Graders of MTs Surya Buana Malang Through Role Play. Jurnal Kependidikan: Jurnal Hasil Penelitian dan Kajian Kepustakaan di Bidang Pendidikan, Pengajaran dan Pembelajaran, 2(2). doi:https://doi.org/10.33394/jk.v2i2.391

Rahmawati, E. (2018). Upaya Meningkatkan Keterampilan Berbicara Bahasa Jerman dengan Metode Rollen Spiel pada Siswa Kelas XI Bahasa di SMA Negeri 3 Mataram. Jurnal Kependidikan: Jurnal Hasil Penelitian dan Kajian Kepustakaan di Bidang Pendidikan, Pengajaran dan Pembelajaran, 4(1), 24-30. doi:https://doi.org/10.33394/jk.v4i1.898

Suarni, G., Rizka, M., \& Zinnurain, Z. (2021). Analisis Pengaruh Penerapan Model Pembelajaran Sains Teknologi Masyarakat Terhadap Hasil Belajar Siswa. Jurnal Paedagogy, 8(1), 31-38. doi:https://doi.org/10.33394/jp.v8i1.3226

Sukardiyanto, Totok. (2015). "Pengertian, Tujuan, Manfaat, Karakteristik, dan Langkahlangkah Penelitian Tindakan Kelas". 15-25

Sukmayati. (2014). "Improving Speaking Ability Of The Eleventh Year Students Of SMA Laboratorium UNSYIAH Banda Aceh By Using Time Token Arends Technique" Getsempena English Education, 1 (2): 36-44

Suyadi. (2012). Panduan Penelitian Tindakan Kelas. Yogyakarta : Diva Press.

Tarigan, Henry Guntur. (2008). Berbicara Sebagai Suatu Keterampilan Berbahasa. Bandung: Angkasa. 